\title{
Tumefactive fibroinflammatory lesion: A rare cause of chest pain
}

\author{
illknur \\ KÜÇÜKOSMANOĞLU ${ }^{1}$ \\ (ID) \\ Meryem ilkay EREN \\ KARANIS $^{1}(I D)$ \\ Bekir TURGUT $^{2}$ (ID) \\ Mustafa ÇALIK ${ }^{3}$ (ID)
}

\author{
${ }^{1}$ Clinic of Pathology, Konya City Hospital, Konya, Turkey \\ ${ }^{1}$ Konya Şehir Hastanesi, Patoloji Kliniği, Konya, Türkiye \\ ${ }^{2}$ Clinic of Radiology, Konya City Hospital, Konya, Turkey \\ ${ }^{2}$ Konya Şehir Hastanesi, Radyoloji Kliniği, Konya, Türkiye \\ ${ }^{3}$ Clinic of Thoracic Surgery, Konya City Hospital, Konya, Turkey \\ ${ }^{3}$ Konya Şehir Hastanesi, Göğüs Cerrahisi Kliniği, Konya, Türkiye
}

Cite this article as: Küçükosmanoğlu i, Eren Karanis Mi, Turgut $B$, Çallk $M$. Tumefactive fibroinflammatory lesion: $A$ rare cause of chest pain. Tuberk Toraks 2021;69(3):403407.

\section{Address for Correspondence (Yazışma Adresi)}

Dr. Illknur KÜÇÜKOSMANOĞLU

Clinic of Pathology, Konya City Hospital

KONYA - TURKEY

e-mail: ilknurkukrer@hotmail.com

(C) Copyright 2021 by Tuberculosis and Thorax.

Available on-line at www.tuberktoraks.org.com

\begin{abstract}
Tumefactive fibroinflammatory lesion: A rare cause of chest pain

Tumefactive fibroinflammatory lesion (TFIL) is a rare idiopathic disease. These lesions clinically mimic malignant neoplasms, but they are characterized by benign histology while they cause local destruction. Its etiology is unknown, but it is thought to be an exaggerated immune response resulting from chronic infections. They are commonly seen in the head and neck area. Similar clinical and histologic findings are also present in IgG4-related disease. Here, it was aimed to present a 75-year-old male patient with chronic diseases including coronary artery disease and obesity. He was admitted to the thoracic surgery outpatient clinic with symptoms of chest pain, dyspnea, and swelling in the anterior chest wall. Imaging methods revealed a mass, which affected bone structures and showed increased 18-fluorodeoxyglucose (FDG) uptake, in the anterior of the left hemithorax. Surgical excision was performed because he met the clinical criteria of malignancy. No malignancy finding was identified in the histopathologic examination of the samples collected from the mass. In light of immunohistochemical and histopathologic findings, he was diagnosed as having TFIL. Treatment options for these lesions include steroids, surgery, and radiotherapy. They are persistent lesions associated with a high recurrence rate. We wanted to present this case because it is possible to recognize this rarely encountered lesion and increase awareness of the existence of such an entity.
\end{abstract}

Key words: Chest pain; mass; tumefactive fibroinflammatory lesion

ÖZ

Tümefaktif fibroinflamatuar lezyon: Göğüs ağrısının nadir bir nedeni

Tümefaktif fibroinflamatuar lezyon (TFIL) nadir görülen idiyopatik bir hastalıktır. Bu lezyonlar, lokal destrüksiyona neden olduğundan, klinik olarak, malign neoplazileri taklit eder ancak benign histoloji ile karakterizedir. Etiyolojisi bilinmemekle birlikte, kronik enfeksiyonlardan kaynaklanan abartıIı bir immün yanıt olduğu düşünülmektedir. Sıklıkla baş ve boyun bölgesinde görülürler. Benzer klinik ve histolojik bulgular, IgG4 ile ilişkili hastalıkta da 
mevcuttur. Burada koroner arter hastalığı ve obezite gibi kronik hastalıkları olan, 75 yaşında bir erkek hastayı sunuyoruz. Göğüs ağrısı, nefes darlığı ve göğüs ön duvarında şişlik şikayetleriyle göğüs cerrahisi polikliniğine başvuran hastada, görüntüleme yöntemleri, sol gögüs ön duvarında, kemik yapılarını destrükte eden ve 18-florodeoksiglukoz (FDG) alımının arttığı gözlenen bir kitle ortaya çıkardı. Klinik olarak malignite kriterlerini karşıladığı için cerrahi eksizyon yapıldı. Kitleden alınan örneklerin histopatolojik incelemesinde malignite bulgusu tespit edilmedi. Immünohistokimyasal ve histopatolojik bulgular ışı̆̆ında TFIL tanısı kondu. Bu lezyonlar için tedavi seçenekleri arasında steroidler, cerrahi ve radyoterapi bulunur. Yüksek nüks oranıyla ilişkili lezyonlardır. Nadiren karşılaşılan bu lezyonu tanımak ve böyle bir lezyonun farkındalığını artırmak için bu vakayı sunmak istedik.

Anahtar kelimeler: Göğüs ağrısı; kitle; tümefaktif fibroinflamatuar lezyon

\section{INTRODUCTION}

TFIL is an idiopathic disease that is rarely encountered. The lesion causes local destruction, it is clinically aggressive but benign histopathologically (1-6). The head and neck regions are the most common site of involvement; extremity involvement is rare. Rice et al. described the first case of the fibrosclerotic lesion in the soft tissue of the neck in 1975 and named it sclerosing cervicitis $(2,7)$. The term TFIL was first used by Wold et al. in $1983(8,9)$. Classification of these lesions is difficult because there are no clear diagnostic criteria. Its etiology is unknown and its treatment is controversial (6).

The general treatment approach is surgery and steroids; however, there are studies showing that immunomodulatory agents and radiotherapy can be applied for lesions in areas unsuitable for surgery and lesions that do not respond to steroids $(4,8)$. They radiologically appear to imitate destructive and malignant processes.
In this manuscript, we described a mass located on the chest wall and clinically mimicking malignancy, which was diagnosed as TFIL and surgically treated, in a 75-year-old male patient.

\section{CASE}

A 75-year-old male patient with chronic diseases including coronary artery disease (CAD) and obesity, who had acute pancreatitis six months ago and underwent cholecystectomy, was admitted to the thoracic surgery outpatient clinic with symptoms of chest pain, dyspnea, and swelling in the anterior chest wall. Whole-body 18F-FDG PET imaging showed a $5 \times 3 \times 2 \mathrm{~cm}$ soft tissue mass in the left anterior hemithorax, starting from the costochondral junction of the left seventh and eighth ribs, extending towards the anterior chest wall, which affected bone structures and showed increased FDG uptake (Figure 1). In computed tomography (CT) imaging of the chest taken two months ago due to symptoms of dys-

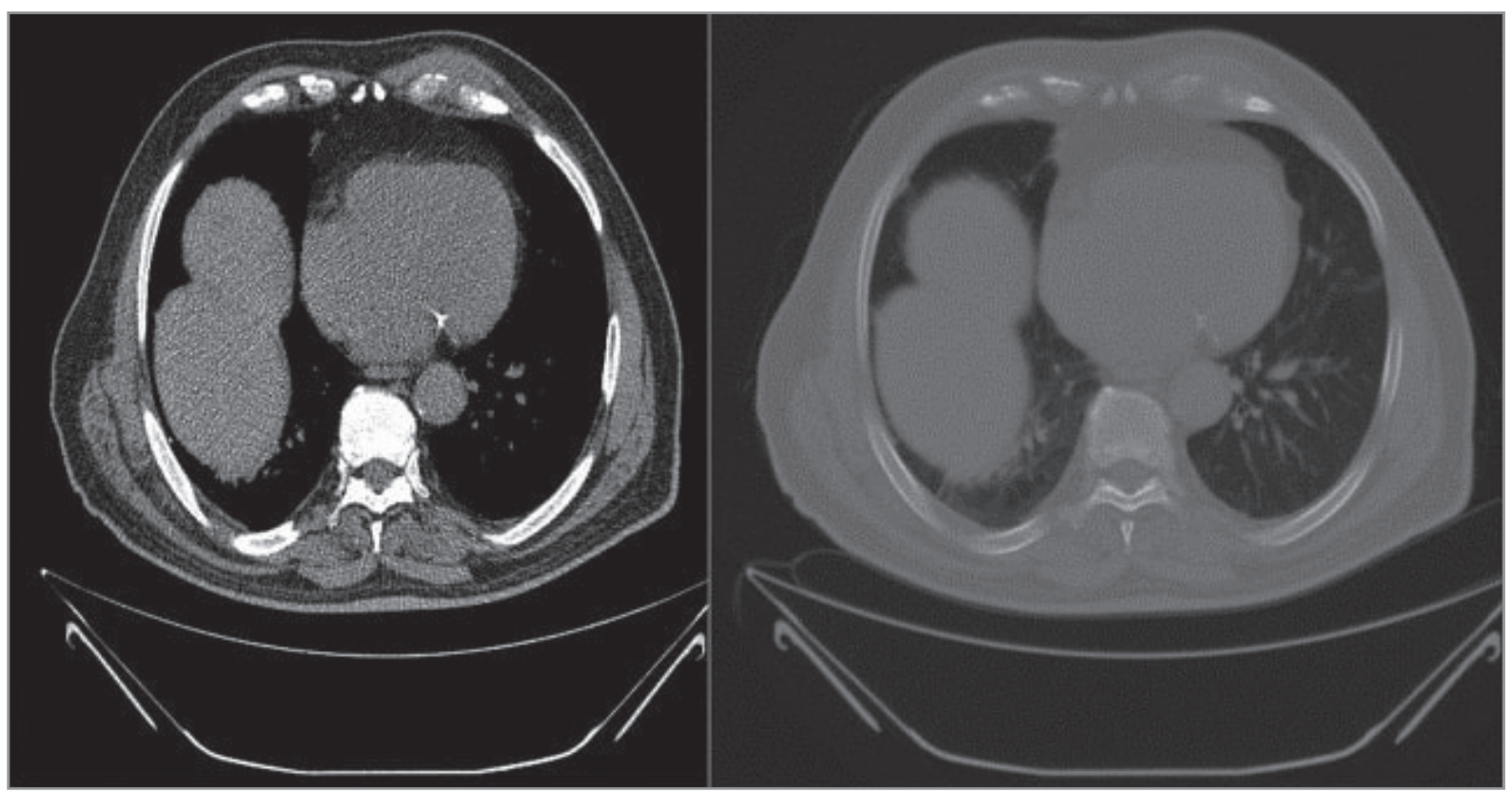

Figure 1. Axial chest CT images obtained at the heart level, bone and mediastinal window. Left $8^{\text {th }}$ rib level, there was a $31 \mathrm{~mm}$ thick tumor-like lesion that involved the costochondral junction and surrounding soft tissue. 


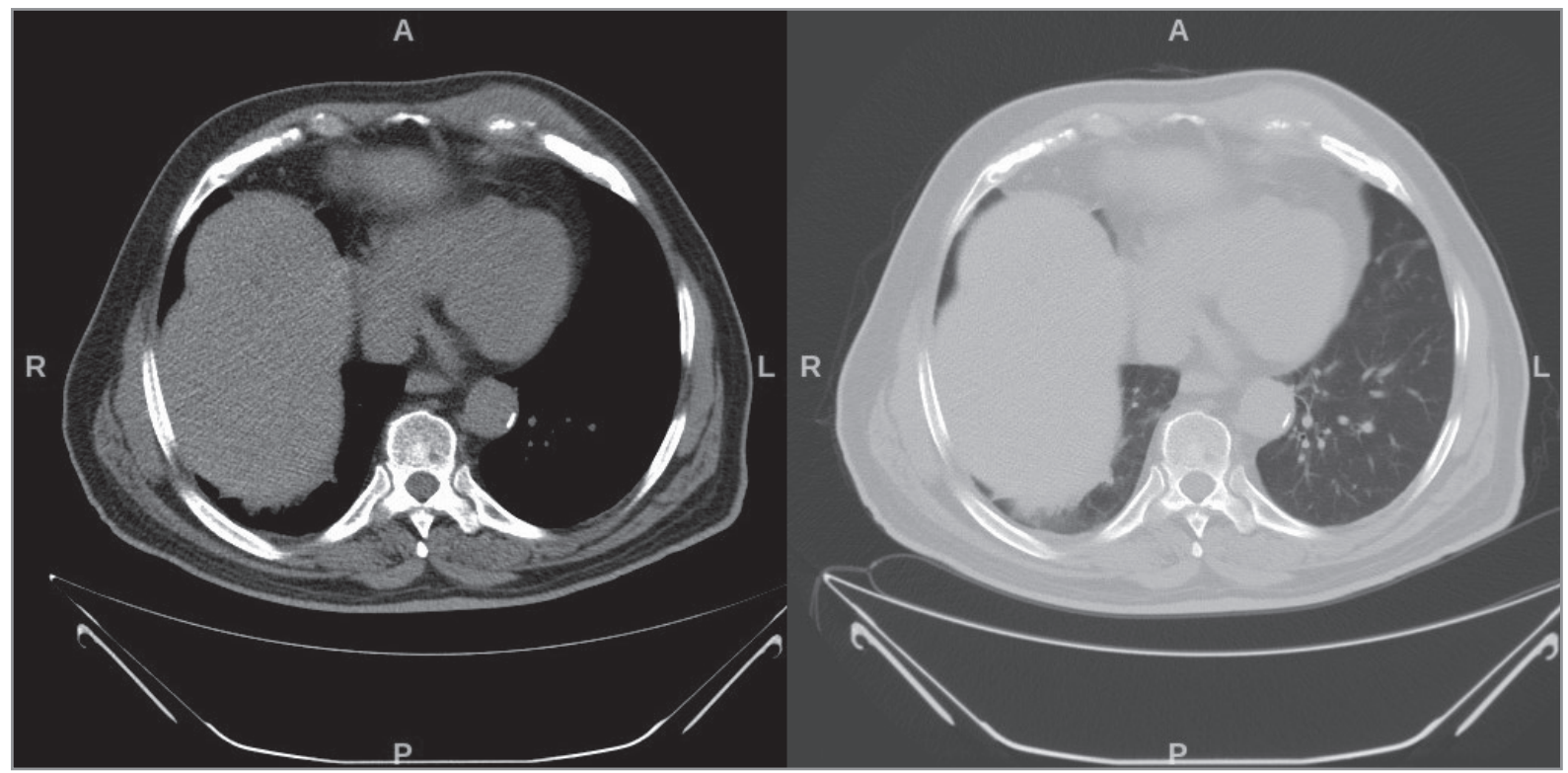

Figure 2. Chest CT scan two months ago.

pnea, there was no finding of the currently identified lesion (Figure 2). Therefore, the mass can be said to have grown rapidly. Surgical excision was performed for diagnostic and therapeutic purposes because the mass met the clinical criteria of malignancy. Ribs excised during the surgery were replaced with prolene mesh. The macroscopic examination of the surgically excised material showed a solid, ill-defined tumoral lesion of about $6 \mathrm{~cm}$ in diameter with elastic consistency, involving three ribs, infiltrating into the adjacent muscle and adipose tissues, and having cross-sections of white color. A frozen section was prepared and the excision material was evaluated intraoperatively. It was stated that the lesion may be an inflammatory myofibroblastic tumor with the findings observed in frozen sections, but definitive diagnosis could be determined in permanent sections. In permanent sections, on microscopic examination, collagenized proliferating fibrous tissue was noted, which destroyed bone tissue (Figure 3), infiltrated into muscle and adipose tissue, had a storiform pattern in places, and was sclerotic in most areas (Figure 4). Within these sclerotic areas, there were lymphoid aggregates forming follicle structures (Figure 5), interstitial lymphoplasmacytic inflammatory cell infiltration (Figure 6), and atrophic muscle fibers. Cytoplasmic positive immunoreactivity was observed in plasma cells with CD138 immunohistochemical staining. A polyclonal staining pattern with kappa and lambda light chains was observed. Histiocyte clusters resem-

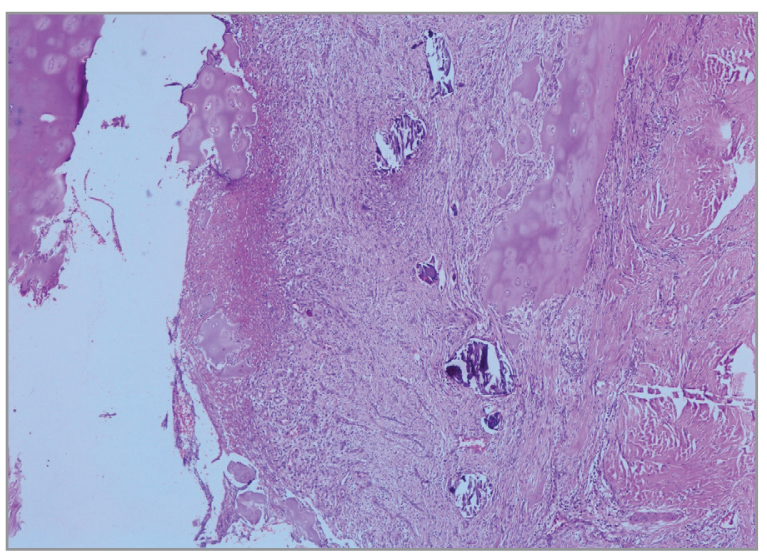

Figure 3. Chronic inflammatory granulation tissue and destruction of the costochondral junction, H\&E staining, x40 magnification.

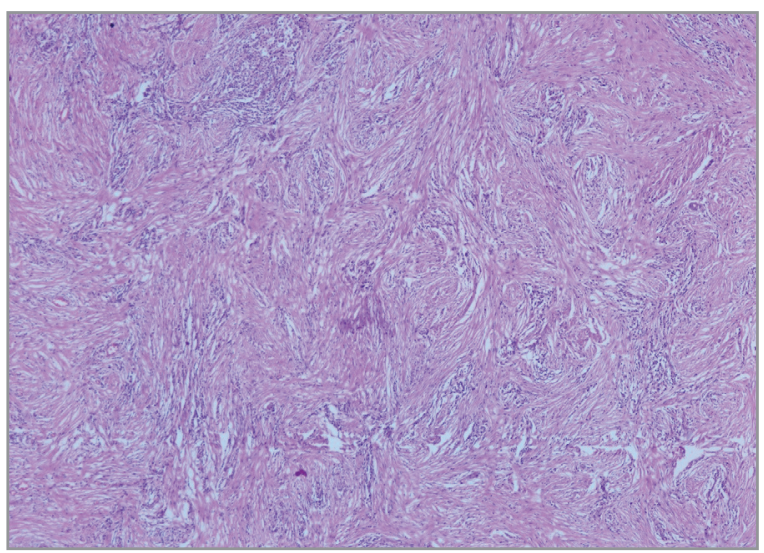

Figure 4. Fibrosis showing a storiform pattern, H\&E staining, x40 magnification. 


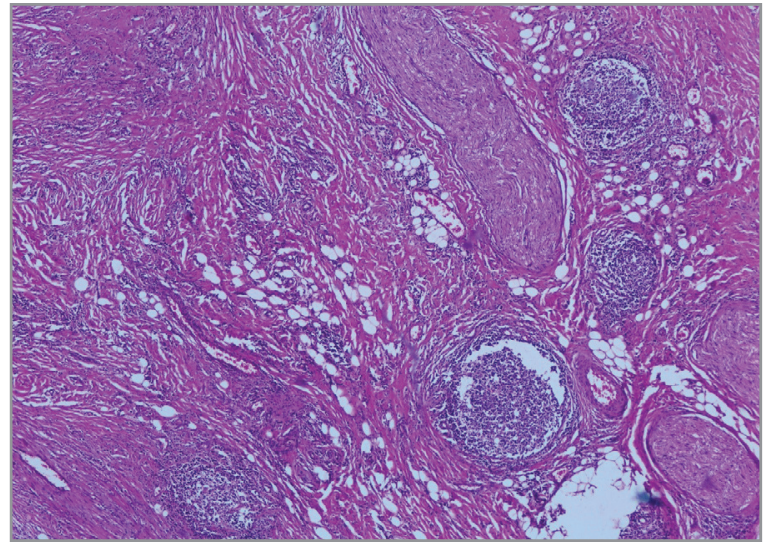

Figure 5. Lymphoid aggregates within collagenized fibrous tissue surrounding neuronal structures, H\&E staining, x100 magnification

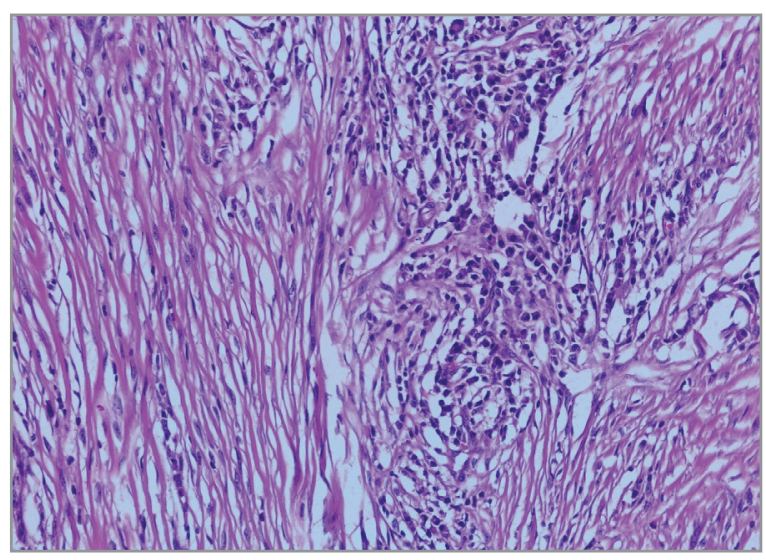

Figure 6. Plasma cell infiltration within the fibrotic stroma, $\mathrm{H} \& \mathrm{E}$ staining, x200 magnification.

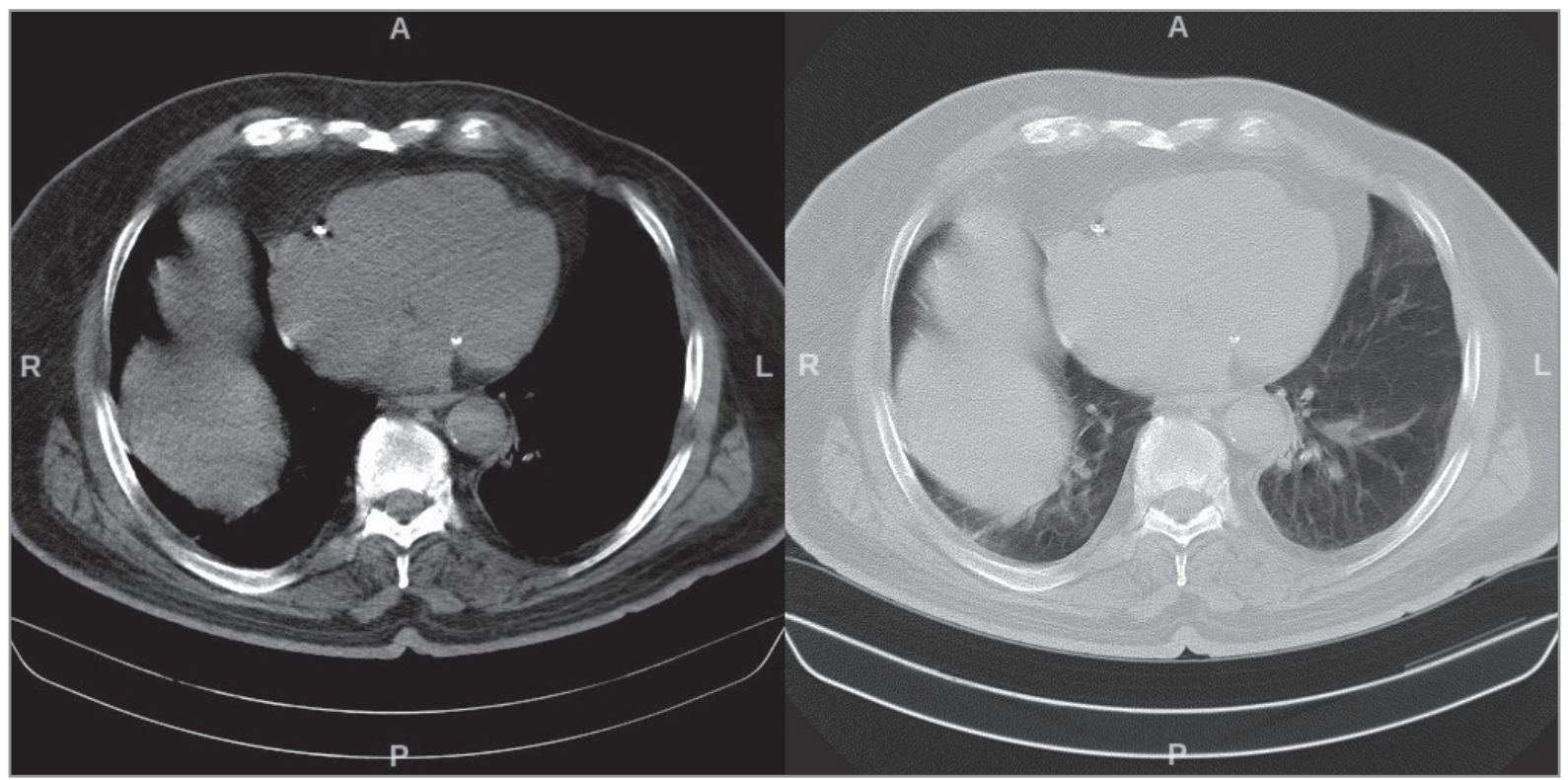

Figure 7. Postoperative chest CT.

bling xanthogranulomatous inflammation and chronic inflammatory granulation tissue were observed in places. Positive staining was observed in fibroblastic cells for smooth muscle actin (SMA) and calponin. No immune reaction was observed in these fusiform cells with desmin, AE1/AE3, S-100, CD34, and anaplastic lymphoma kinase (ALK), which were applied immunohistochemically for differential diagnosis. Furthermore, no specific infectious agent was demonstrated via Erlich-Ziehl-Neelsen (EZN), and periodic acid-Schiff (PAS) staining. In the case, serum IgG4 level was within normal limits. The patient was diagnosed as having TFIL based on radiologic, clinical, and histopathologic findings. He received no treat- ment other than surgery, and no recurrence was observed in the examination performed at the post-treatment $18^{\text {th }}$ month (Figure 7 ).

\section{CONCLUSION}

TFIL is a rare idiopathic disease, the etiopathogenesis of which has not yet been fully understood. It is thought to show an exaggerated host immune response to unidentified infectious agents, necrotic tissues, foreign bodies, and viral infections. TFILs usually present with painful large masses. They radiologically appear to imitate destructive and malignant processes. It is hard to establish a diagnosis clinically $(1,2)$. It is a form of inflammatory pseudotumor. 
Inflammatory myofibroblastic tumor (IMT) and IgG4related disease (IgG4-RD) are also included in this group (4).

In microscopic examination, it presents with collagenized proliferated fibrous tissue without necrosis and mitosis which is cytologically atypical and can destroy bone tissue and infiltrate into muscle and adipose tissues, as well as into the adjacent vascular and neural structures. Within this fibrous stroma, there were lymphoid aggregates forming follicle structures and interstitial lymphoplasmacytic inflammatory cell infiltration (1).

Differential diagnosis of this lesion includes IMT, a fusiform cell proliferation that contains various inflammatory cells. It is more common among adolescents and children. Positive IHC staining is observed with ALK in $50 \%$ of cases (8). More well-circumscribed masses are created by IMT and it is often observed in the mesentery, omentum, and peritoneum. Eosinophils are also included in inflammatory cells $(5,8)$. Intranuclear eosinophilic inclusions and ALK positivity observed in IMT are not seen in TFILs (4). The lesion in the present case was not found compatible with IMT, considering the age, location and microscopic features, and ALK negativity.

The IgG4-RD is associated with storiform fibrosis and IgG4 positive plasma cells. Recent studies supported that TFIL was a variation of IgG4-RD (3). T helper type 2 (Th2) cells have an important role in IgG4-RD. These cells express interleukin IL-4, IL-5, IL-10, and IL-13, as well as transforming growth factor-beta (TGF- $\beta$ ). These molecules lead to fibroblast activation and fibrosis $(4,10)$.

Its treatment is controversial, and because the number of cases is low, personalized treatment is recommended $(3,4)$. Steroid therapy, surgical excision, and radiotherapy are among the treatment options. This is followed by surgical treatment and radiotherapy. Surgical excision can be performed for steroid-unresponsive lesions or radiotherapy can be preferred for lesions that cannot be removed surgically or in the presence of residue $(1,10)$.

The definitive diagnosis is only made by open biopsy and there is no consensus about the therapeutic approach. Recurrence and persistent disease are common. The present case is currently in the $18^{\text {th }}$ month post-treatment and no evidence of recurrence has been observed. It is possible to recognize this rarely encountered lesion and physicians should be aware of the existence of such an entity.

\section{CONFLICT of INTEREST}

The authors reported no conflict of interest related to this article.

\section{AUTHORSHIP CONTRIBUTIONS}

Concept/Design: IK, MIEK

Analysis/Interpretation: IK, MIEK

Data Acquisition: IK, MC

Writing: IK, MIEK

Critical Revision: All of authors

Final Approval: All of authors

\section{REFERENCES}

1. Jain P, Sen R, Sharma N, Bhargava S, Singh V. Tumefactive fibroinflammatory lesion: A diagnostic dilemma. Iran I Med Sci 2017; 42(2): 205-9.

2. Binesh F, Taghipour SH, Navabii H. Tumefactive fibroinflammatory lesion: a rare aetiology for a neck mass in an old Iranian man. BMJ Case Rep 2011; bcr1220103572: $1-3$

3. Kusaka S, Nishimura S, Kawakami F, Ohbayashi C, Shibuya $Y$, Iwata K. Tumefactive fibroinflammatory lesion presenting with head and neck fibrosclerosing lesions and orbital pseudotumors: a case report. I Med Case Rep 2013; 7: 260

4. Bishop IL, Bryan LJ, Savage NM, Byrd JK. Tumefactive fibroinflammatory lesion successfully treated with Rituximab. Intractable Rare Dis Res 2019; 8(2): 138-41.

5. Campbell SN, Rubio E, Loschner AL. Clinical review of pulmonary manifestations of IgG4-related disease. Ann Am Thorac Soc 2014; 11(9): 1466-75.

6. Holodny Al, Kirsch CF, Hameed M, Sclar G. Tumefactive fibroinflammatory lesion of the neck with progressive invasion of the meninges, skull base, orbit, and brain. AJNR Am J Neuroradiol 2001; 22(5): 876-9.

7. Wold LE, Weiland $L H$. Tumefactive fibro-inflammatory lesions of the head and neck. The Am / Surg Pathol 1983; $7(5)$ : 477-82

8. Hoebers FJ, Ordonez BP, Irish J, Simpson RE, Yu E, O'Sullivan B. Progressive tumefactive fibroinflammatory lesion of the infratemporal fossa treated by radiation therapy. Rare Tumors 2012; 4(1): 32-6.

9. Rice DH, Batsakis JG, Coulthard SW. Sclerosing cervicitis: homologue of sclerosing retroperitonitis and mediastinitis. Arch Surg 1975; 110(1): 120-2.

10. Ryu JH, Sekiguchi H, Yi ES. Pulmonary manifestations of immunoglobulin G4-related sclerosing disease. Eur Respir J 2012; 39(1): 180-6. 